\title{
Evaluasi Toleransi Genotipe Kacang Hijau terhadap Cekaman Salinitas
}

\section{Evaluation of Mungbean Genotypes Tolerance to Salinity Stress}

\author{
Trustinah*, Abdullah Taufiq, dan Rudi Iswanto \\ Balai Penelitian Tanaman Aneka Kacang dan Umbi \\ J1. Raya Kendalpayak KM 8, Kotak Pos 66, Malang, Indonesia
}

Diterima 27 April 2017/Disetujui 23 Agustus 2018

\begin{abstract}
Salinity has become a serious problem in the production of food crops in Indonesia, especially in coastal areas. Mungbeans is one of commodities which can be grown in coastal areas during the dry season. Research to evaluate tolerance

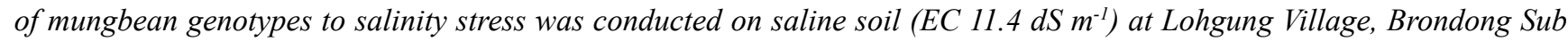
District, Lamongan District during dry season May-July in 2016. A 100 of mungbean genotypes were evaluated using a randomized block design, replicated twice. The majority of the genotypes (82\%) were categorized between sensitive to very sensitive to salinity stress. All of the genotypes grew normally to generative phase and produced 2-9 pods per plant with seed yield ranged 0.04-0.60 ton ha-1. The tolerant genotypes had higher plant height, stover weight, and yield than the sensitive

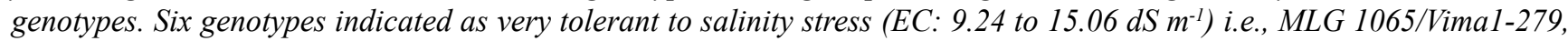
MMC 464c-gt-4-0-3, MMC 678-8c-gt-5, Vima 1/MLG 1065-286, MLG 1065/Vima1-276 and Vima1/Sampeong//Vima1-249. Seven genotypes indicated as tolerant to salinity stress i.e., Vima1/MLG1065-290, MLG1065/Vima1-272, MLG1065/Vima1274, Vima1/MLG 1065-287, Vima1/MLG 1065-276, MMC 267c-mn-1-1-11, and VIMA 1/MLG 1065-288. These selected genotypes were potential to be developed into new mungbean variety tolerant to salinity.
\end{abstract}

Keywords: electrical conductivity, growth, yield, selection, Vigna radiata

\section{ABSTRAK}

Salinitas menjadi masalah serius dalam produksi tanaman pangan di Indonesia khususnya pada daerah-daerah yang terletak di dekat pantai. Tanaman kacang hijau merupakan salah satu komoditas yang dapat ditanam di daerah pantai pada musim kemarau. Penelitian yang bertujuan mengevaluasi toleransi genotipe kacang hijau terhadap cekaman salinitas dilaksanakan pada lahan salin (rata-rata DHL 11.4 dS $\mathrm{m}^{-1}$ ) di Desa Lohgung, Kecamatan Brondong, Kabupaten Lamongan pada bulan Mei-Juli tahun 2016. Sebanyak 100 genotipe kacang hijau dievaluasi menggunakan rancangan acak kelompok, diulang dua kali. Sebagian besar genotipe (81\%) yang diuji menunjukkan respon peka hingga sangat peka. Semua genotipe dapat melewati fase generatif dan menghasilkan 2-9 polong per tanaman, dan hasil biji berkisar antara 0.04-0.60 ton ha-1. Genotipe yang toleran pertumbuhannya normal, dan memiliki tinggi tanaman, bobot brangkasan, serta hasil lebih tinggi dibandingkan genotipe yang peka. Terdapat enam genotipe terindikasi sangat toleran dan tujuh genotipe terindikasi toleran cekaman salinitas pada DHL tanah 9.24-15,06 dS m-1. Enam genotipe sangat toleran adalah MLG 1065/Vima1-279, MMC 464c-gt-4-0-3, MMC 678-8c-gt-5, Vima 1/MLG 1065-286, MLG 1065/Vima1-276 dan Vima1/Sampeong//Vima1-249, serta tujuh genotipe toleran adalah Vima1/MLG1065-290, MLG1065/Vima1-272, MLG1065/Vima1-274, Vima1/MLG 1065-287, Vima1/MLG 1065-276, MMC 267c-mn-1-1-11, dan VIMA 1/MLG 1065-288. Genotipe tersebut berpeluang dikembangkan lebih lanjut menjadi varietas unggul baru toleran salin.

Kata kunci: daya hantar listrik, hasil, pertumbuhan, seleksi, Vigna radiata

\section{PENDAHULUAN}

Tanaman kacang hijau (Vigna radiata L. Wilczek) merupakan salah satu komoditas yang banyak ditanam di daerah pantai pada musim kemarau. Pada lahan yang

\footnotetext{
* Penulis untuk korespondensi. e-mail: trustinah02@yahoo.com
}

terletak di dekat pantai, salinitas telah menjadi masalah serius dalam produksi tanaman pangan di Indonesia. Hal ini disebabkan masuknya air laut akibat bencana alam seperti tsunami, dan intrusi air laut akibat pengaruh pasang surut air laut. Dampak salinitas semakin parah pada musim kemarau. Salinitas menyebabkan tanaman mengalami nekrosis dan klorosis, serta berakibat menurunkan bahan kering dan hasil (Naher dan Alam, 2010, Kumar et al., 2012, Sehrawat et al., 
2015). Peningkatan cekaman akan menyebabkan persentase kecambah abnormal semakin meningkat (Saha et al., 2010, Kandil et al., 2012). Jones (2002) mengelompokkan salinitas tanah ke dalam non salin (DHL $<1.0 \mathrm{dS} \mathrm{m}^{-1}$ ), sangat rendah (DHL 1.1-2.0 dS m ${ }^{-1}$, hasil tanaman yang sangat peka turun 25-50\%), sedang (DHL 2.1-4.0 dS m ${ }^{-1}$, hasil tanaman yang peka turun 25-50\%), agak tinggi (DHL 4.0-8.0 dS m $\mathrm{d}^{-1}$, hanya tanaman yang toleran yang dapat tumbuh), dan tinggi (DHL 8.1-16.0 dS $\mathrm{m}^{-1}$ ).

Toleransi kacang hijau terhadap salinitas beragam antar genotipe. Kacang hijau tidak mampu berpolong pada DHL $12 \mathrm{dS} \mathrm{m}^{-1}$ (Ahmed, 2009), tumbuh dan membentuk polong pada DHL 1.79-12.49 dS m ${ }^{-1}$ (Taufiq dan Purwaningrahayu, 2013). Hasil kacang hijau turun $10-50 \%$ pada DHL 1.5-3.3 $\mathrm{dS} \mathrm{m} \mathrm{m}^{-1}$ (Cardon et al., 2007), turun 29-33\% pada DHL $8.0 \mathrm{dS} \mathrm{m} \mathrm{m}^{1}$ (Kumar et al., 2012),. Batas kritis kacang hijau terhadap salinitas berdasarkan penurunan hasil adalah 1.8 $\mathrm{dSm}^{-1}$ (Yadav et al., 2011), 1.79-2.65 dS m $\mathrm{d}^{-1}$ (Taufiq dan Purwaningrahayu, 2013), dan 1.5-3.3 $\mathrm{dS} \mathrm{m}^{-1}$ (Cardon et al., 2007).

Toleransi didefinisikan sebagai kemampuan tanaman untuk tetap tumbuh dan berproduksi pada lingkungan yang tercekam. Toleransi kacang hijau terhadap salinitas berhubungan dengan kemampuannya mengakumulasi unsur kalium dan air dalam daun, mengandung prolin dan glycinebetain lebih banyak, dan degradasi klorofil lebih rendah (Dutta dan Bera, 2014, Hossain et al., 2008). Genotipe toleran mengakumulasi Na pada akar (MurilloAmador et al., 2006). Genotipe toleran mempunyai hasil dan komponen hasil lebih tinggi dibanding yang peka (Mensah dan Ihenyen, 2009, Sehrawat et al., 2015).

Evaluasi sumber daya genetik untuk salinitas dapat dilakukan di rumah kaca atau di lapang dengan jumlah aksesi yang lebih sedikit. Singh dan Singh (2011) mengemukakan bahwa skrining lapang adalah cara yang tepat untuk evaluasi plasma nutfah dan bahan pemuliaan terhadap cekaman abiotik. Pada pengujian di rumah kaca, galur kacang hijau F3 memberikan respon yang beragam terhadap salinitas, dari toleran hingga sangat peka (Trustinah et al., 2016). Cekaman salinitas berat sejak awal pertumbuhan menyebabkan sedikit tanaman yang mampu bertahan hidup hingga panen dan sedikit menghasilkan polong. Pada cekaman berat setelah tanaman berkecambah, tanaman masih dapat tumbuh hingga panen, postur lebih tinggi, dan sebagian besar menghasilkan polong rata-rata 2 polong per tanaman (Trustinah et al., 2016). Penelitian bertujuan untuk mengevaluasi toleransi genotipe kacang hijau terhadap cekaman salinitas.

\section{BAHAN DAN METODE}

Pengujian dilaksanakan pada lahan salin dekat pantai di Desa Lohgung, Kecamatan Brondong, Kabupaten Lamongan (6053'59.89801" S; 112 ${ }^{\circ} 11^{\prime} 15.31277^{\prime \prime} \mathrm{E} ; 26 \mathrm{~m}$ dpl) pada musim kemarau tahun 2016 (periode bulan Mei hingga Juli). Daya hantar listrik (DHL) tanah lapisan 0$10 \mathrm{~cm}$ sebelum tanam adalah $11.4 \mathrm{dS} \mathrm{m}^{-1}$. Sebanyak 100 genotipe kacang hijau ditanam menggunakan rancangan acak kelompok, diulang dua kali. Sebagai perlakuan adalah
100 genotipe kacang hijau. Setiap genotipe ditanam pada plot $0.8 \mathrm{~m}$ x $5 \mathrm{~m}$ ( 2 baris, sepanjang $5 \mathrm{~m})$, jarak tanam 40 $\mathrm{cm} \times 10 \mathrm{~cm}$, dua tanaman per rumpun. Pupuk dasar $22.5 \mathrm{~kg}$ $\mathrm{N}, 36 \mathrm{~kg} \mathrm{P} \mathrm{O}_{5}$ dan $30 \mathrm{~kg} \mathrm{~K}_{2} \mathrm{O}$ per hektar, seluruhnya disebar pada barisan tanaman saat tanam. Seminggu sebelum tanam, lahan disemprot dengan herbisida Isopropilamina Glifosat $486 \mathrm{~g} \mathrm{~L}^{-1}$ (merk dagang Roundup) dengan konsentrasi $2 \mathrm{~mL}$ $\mathrm{L}^{-1}$ air untuk mengendalikan gulma. Pengendalian gulma selanjutnya dilakukan saat tanaman berumur 2 dan 4 minggu setelah tanam (MST) secara manual. Pengairan dilakukan pada saat tanam, umur 4 dan 6 MST. Pengendalian hama dan penyakit dilakukan menggunakan pestisida kimia yang sesuai. Panen dilakukan saat polong masak, yang ditandai oleh warna kulit polong berwarna hitam/coklat.

Pengamatan terdiri atas umur 50\% berbunga, tinggi tanaman dan bobot brangkasan saat panen, jumlah polong isi, panjang polong, hasil biji, skor pertumbuhan, dan skor penyakit bercak daun. Skor pertumbuhan mengacu pada skor evaluasi standar untuk tanaman padi (Gregorio et al., 1997) dengan nilai skor 1-9 (sangat toleran hingga sangat peka). DHL tanah lapisan $0-10 \mathrm{~cm}$ diamati langsung di lapang setiap dua minggu menggunakan portable EC meter tipe HI993310 merk Hanna.

Pendugaan parameter genetik (ragam dan koefisien keragaman genotipik dan fenotipik, heritabilitas dalam arti luas, serta korelasi) mengacu pada Vekariya dan Revar (2010)

\section{HASIL DAN PEMBAHASAN}

\section{Pertumbuhan Tanaman}

Hasil analisis ragam menunjukkan hasil dan komponen hasil berbeda nyata antar genotipe yang diuji di lahan salin, kecuali panjang polong, dan jumlah biji per polong. Kisaran umur berbunga antara 33-40 hari setelah tanam, tinggi tanaman umur 8 minggu $16.6-84.5 \mathrm{~cm}$ (ratarata $29.8 \mathrm{~cm}$ ), bobot brangkasan $/ 5$ tanaman 14-139.5 g (rata-rata $43.2 \mathrm{~g}$ ), jumlah polong isi per tanaman 2-9 polong (rata-rata 5), bobot 100 biji 2.56-5.89 g, dan hasil biji 0,040.60 ton $\mathrm{ha}^{-1}$ (rata-rata 0.17 ton $\mathrm{ha}^{-1}$ ) (Tabel 1). Daya hantar listrik (DHL) tanah pada saat tanam tergolong tinggi (11.4 $\mathrm{dS} \mathrm{m}^{-1}$ ), menunjukkan bahwa kondisi lingkungan sangat salin pada awal pertumbuhan. Pada umur 4 MST, 63\% dari genotipe yang diuji memiliki skor pertumbuhan 1-3, yang berarti tanaman masih tumbuh normal-agak normal, namun gejala cekaman sudah terlihat pada ujung daun, yaitu daun berwarna keputihan dan menggulung. Indikasi cekaman semakin tinggi pada umur 6 MST (fase reproduktif), dan respon genotipe semakin jelas yang ditunjukkan oleh keragaan pertumbuhan tanaman dari normal hingga tidak normal. Berdasarkan skor pertumbuhan pada umur $6 \mathrm{MST}$, sebanyak $13 \%$ genotipe dengan skor 1 (sangat toleran), $28 \%$ genotipe dengan skor 3 (toleran), dan 32\% genotipe dengan skor 5 (agak toleran) (Gambar 2), sedangkan genotipe lainnya tergolong peka hingga sangat peka. Pada umur 8 MST, hanya 6 genotipe yang sangat toleran (skor 1), 7 genotipe tergolong toleran (skor 3), dan 9 genotipe tergolong 
agak toleran (skor 5), sedangkan genotipe lainnya tergolong peka dan sangat peka (Tabel 2). Enam genotipe yang sangat toleran salin adalah MLG 1065/Vima1-279, MMC 464c-gt4-0-3, MMC 678-8c-gt-5, Vima 1/MLG 1065-286, MLG 1065/Vima1-276 dan Vima1/Sampeong//Vima1-249, serta 7 genotipe yang tergolong toleran salin adalah Vima1/ MLG1065-290, MLG1065/Vima1-272, MLG1065/Vima1274, Vima1/MLG 1065-287, Vima1/MLG 1065-276, MMC 267c-mn-1-1-11, dan VIMA 1/MLG 1065-288 (Tabel 3).

Data skor pertumbuhan (Tabel 2) tersebut juga menunjukkan bahwa tingkat cekaman salinitas makin parah dengan bertambahnya umur tanaman. Tinggi tanaman saat berumur 6 MST dan 8 MST (saat panen) berturutturut adalah $13.5-40.5 \mathrm{~cm}$ dan $16.6-84.5 \mathrm{~cm}$, serta bobot brangkasan 5 tanaman pada 8 MST 14.0-139.5 g (Tabel 1). Genotipe dengan keragaan tanaman tertinggi adalah MLG
1065/Vima 1-279 dan terpendek adalah Vima 1/Mmc 6723-c-gt-1.

Dari beberapa penelitian dilaporkan, gejala keracunan akibat garam pada salinitas ditandai oleh pertumbuhan tanaman kerdil, klorosis dan nekrosis pada daun muda maupun daun tua, ukuran daun lebih kecil dengan warna lebih hijau, daun cepat gugur, dan pada kondisi parah daun menjadi kuning, dan tepi daun mengering (Sehrawat et al., 2015, Trustinah et al., 2016). Cekaman salinitas tinggi (DHL $11.5 \mathrm{dS} \mathrm{m}^{-1}$ ) sejak awal pertumbuhan menyebabkan galur kacang hijau generasi F3 sebagian besar tidak bertahan hidup hingga panen dan berpolong sangat sedikit (Trustinah et al., 2016).

Perubahan tingkat cekaman nampaknya berkaitan dengan DHL tanah, yang meningkat sejak tanam hingga tanaman berumur 45 hari setelah tanam (HST) atau umur 6

Tabel 1. Statistik deskriptif peubah hasil dan komponen hasil 100 genotipe kacang hijau pada lahan salin, Lamongan, MeiJuli 2016

\begin{tabular}{|c|c|c|c|c|c|c|}
\hline No & Peubah yang diamati & $\begin{array}{c}\text { Pengaruh } \\
\text { genotipe }\end{array}$ & Rata-rata & Kisaran & $\mathrm{KKG}(\%)$ & $\begin{array}{c}\text { Heritabilitas } \\
\text { (arti luas) }\end{array}$ \\
\hline 1 & Tinggi tanaman 6 MST $(\mathrm{cm})$ & $* *$ & 24.30 & $13.5-40.5$ & 17.5 & 0.47 \\
\hline 2 & Tinggi tanaman 8 MST $(\mathrm{cm})$ & $* *$ & 29.80 & $16.6-84.5$ & 21.8 & 0.40 \\
\hline 3 & Bobot brangkasan 5 tanaman saat panen $(\mathrm{g})$ & $* *$ & 43.20 & $14.0-139.5$ & 42.5 & 0.57 \\
\hline 4 & Umur berbunga (HST) & $* *$ & 36.00 & $33-40$ & 3.04 & 0.47 \\
\hline 5 & Jumlah polong isi per tanaman & $* *$ & 4.60 & $2.2-9.1$ & 23.4 & 0.47 \\
\hline 6 & Bobot polong 5 tanaman $(\mathrm{g})$ & $* *$ & 12.70 & $4.0-44.0$ & 45.7 & 0.63 \\
\hline 7 & Bobot biji 5 tanaman (g) & $* *$ & 7.15 & $2.60-20.5$ & 37.7 & 0.54 \\
\hline 8 & Bobot 100 biji (g) & $* *$ & 4.37 & $2.56-5.89$ & 14.0 & 0.65 \\
\hline 9 & Hasil biji (ton ha' ${ }^{-1}$ ) & $* *$ & 0.17 & $0.04-0.60$ & 58.5 & 0.64 \\
\hline 10 & Skor pertumbuhan $4 \mathrm{MST}$ & - & 3.30 & $1-5$ & - & - \\
\hline 11 & Skor pertumbuhan $6 \mathrm{MST}$ & - & 4.50 & $1-9$ & - & - \\
\hline 12 & Skor penyakit bercak daun & - & 4.90 & $3-5$ & - & - \\
\hline
\end{tabular}

Keterangan: ** masing-masing nyata pada uji F 1\%, KKG = koefisien keragaman genetik, MST = minggu setelah tanam, “- " tidak diuji

Tabel 2. Skor pertumbuhan 100 genotipe kacang hijau pada lahan salin dengan daya hantar listrik (DHL) tanah awal 11.4 $\mathrm{dS} \mathrm{m} \mathrm{m}^{-1}$. Lamongan, Mei-Juli 2016

\begin{tabular}{|c|c|c|c|c|}
\hline \multirow{2}{*}{ Skor } & \multirow{2}{*}{ Keterangan } & \multicolumn{3}{|c|}{ Jumlah genotipe } \\
\hline & & $4 \mathrm{MST}$ & $6 \mathrm{MST}$ & $8 \mathrm{MST}$ \\
\hline 1 & Tanaman tumbuh normal, tidak ada gejala keracunan (sangat toleran) & $\begin{array}{c}24 \\
(24 \%)\end{array}$ & $\begin{array}{c}13 \\
(13 \%)\end{array}$ & $\begin{array}{c}6 \\
(6 \%)\end{array}$ \\
\hline 3 & $\begin{array}{l}\text { Tanaman agak normal, tetapi ujung daun atau beberapa daun berwarna } \\
\text { keputihan dan menggulung (toleran) }\end{array}$ & $\begin{array}{c}39 \\
(39 \%)\end{array}$ & $\begin{array}{c}28 \\
(28 \%)\end{array}$ & $\begin{array}{c}7 \\
(7 \%)\end{array}$ \\
\hline 5 & $\begin{array}{l}\text { Pertumbuhan agak terganggu, sebagian besar daun menggulung dan hanya } \\
\text { sedikit yang memanjang (agak toleran) }\end{array}$ & $\begin{array}{c}37 \\
(37 \%)\end{array}$ & $\begin{array}{c}32 \\
(32 \%)\end{array}$ & $\begin{array}{c}9 \\
(9 \%)\end{array}$ \\
\hline 7 & $\begin{array}{l}\text { Pertumbuhan terhambat, sebagian besar daun mengering, beberapa tanaman } \\
\text { mati (peka) }\end{array}$ & & $\begin{array}{c}24 \\
(24 \%)\end{array}$ & $\begin{array}{c}53 \\
(53 \%)\end{array}$ \\
\hline 9 & Hampir seluruh tanaman mati atau mengering (sangat peka) & & $\begin{array}{c}3 \\
(3 \%)\end{array}$ & $\begin{array}{c}25 \\
(25 \%)\end{array}$ \\
\hline
\end{tabular}


MST, dan kemudian DHL turun pada saat tanaman berumur 60 HST atau umur 8 MST (Gambar 1). Peningkatan DHL pada tanah lapisan atas terjadi karena adanya akumulasi garam dari lapisan bawah yang terbawa air selama proses evaporasi (Zhang et al., 2008; Abou-Baker et al., 2011; Swarup 2013; Alharbi, 2015). Pada periode akhir pertumbuhan sering terjadi hujan sehingga DHL tanah turun, meskipun masih dalam kategori tinggi. Fluktuasi DHL tanah salin selalu terjadi selama periode pertumbuhan tanaman akibat pengaruh perubahan kondisi lingkungan, sehingga tanaman harus mampu bertahan pada rentang tingkat salinitas tanah selama periode pertumbuhannya. Dengan demikian, evaluasi toleransi terhadap cekaman salinitas harus dilakukan selama satu siklus pertumbuhan tanaman (dari tanam hingga panen).

\section{Hasil dan Komponen Hasil}

Semua genotipe yang diuji dapat melewati fase generatif yang ditunjukkan oleh tanaman dapat berbunga, pengisian polong, dan menghasilkan polong. Jumlah polong yang dihasilkan berkisar antara 2-9 polong per tanaman, dan hasil biji 0.04-0.60 ton ha-1 (Tabel 1). Sebagian besar genotipe yang diuji memiliki tinggi tanaman, bobot brangkasan, dan hasil di bawah rata-rata masing-masing sebanyak 61, 63, dan 61 genotipe (Gambar 2).

Tanah salin umumnya mempunyai kandungan liat tinggi dan struktur tanah masif sehingga berdrainase buruk. Curah hujan yang cukup tinggi saat menjelang berbunga hingga panen menyebabkan kelembaban tanah meningkat
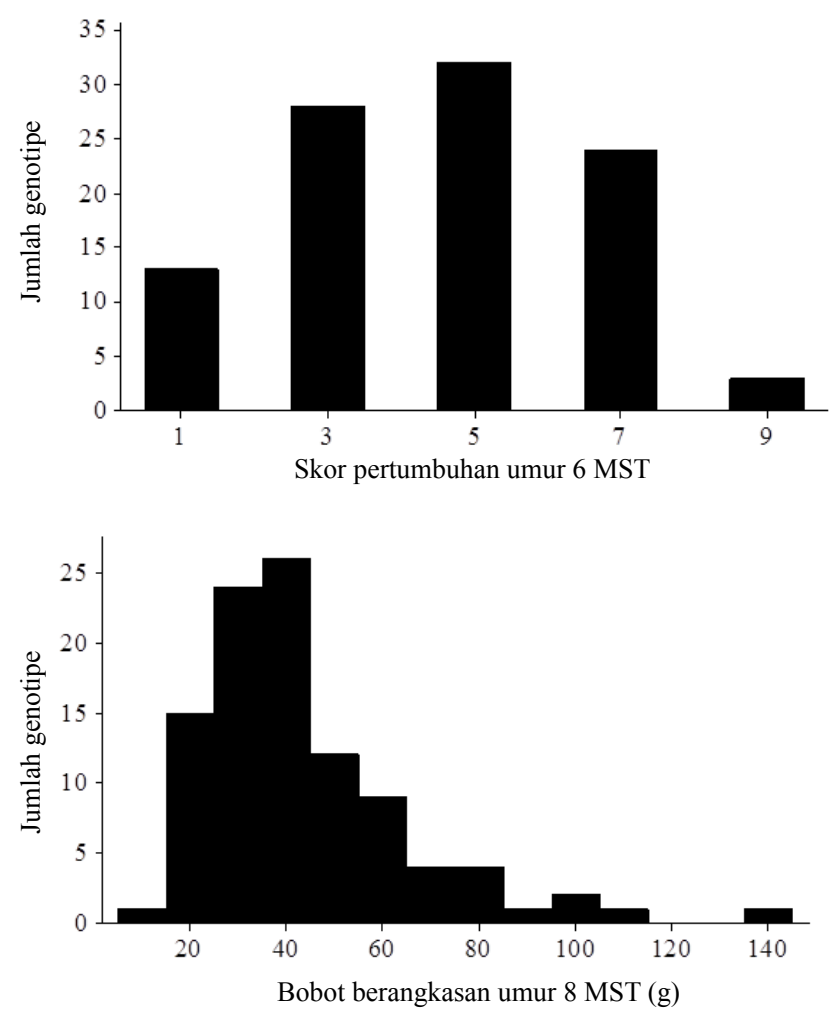

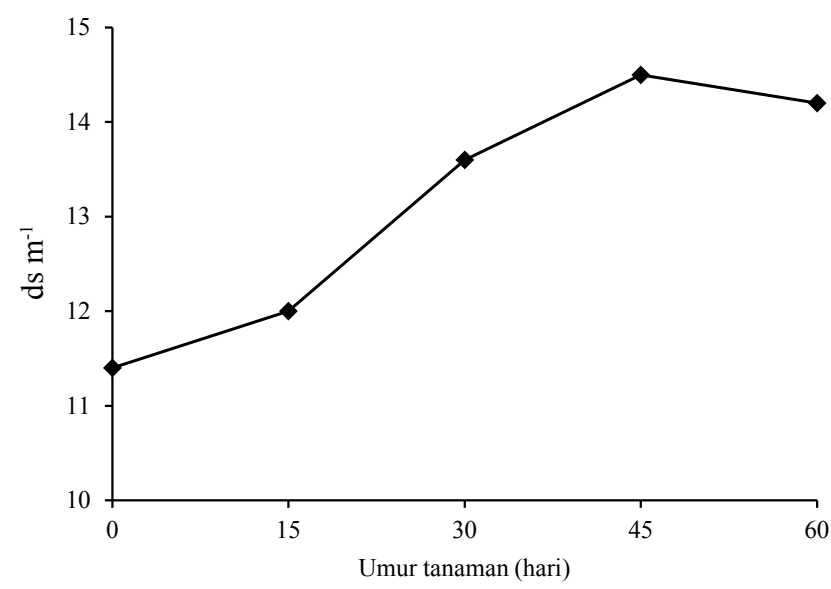

Gambar 1. Daya hantar listrik (DHL) tanah lokasi penelitian (Lamongan, Mei-Juli 2016) pada lapisan 0-10 cm sejak tanam hingga tanaman kacang hijau berumur 60 hari

sehingga muncul serangan penyakit bercak daun dengan intensitas sangat tinggi yang menyebabkan daun kering dan rontok. Sebagian besar genotipe tergolong rentan hingga sangat rentan terhadap penyakit daun (skor 4-5) (Tabel 3). Terdapat tiga genotipe MMC 678-8c-gt-5, MMC 464cgt-4-0-3, dan MMC 267c-mn-1-1, yang toleran terhadap salinitas dan agak tahan terhadap penyakit bercak daun yang ditunjukkan dengan penampilan tanaman yang sehat (skor pertumbuhan 1-3), tinggi tanaman sekitar $40 \mathrm{~cm}$, panjang dan lebar daun $11 \mathrm{~cm}$ dan $9 \mathrm{~cm}$, daun hijau, dan tidak
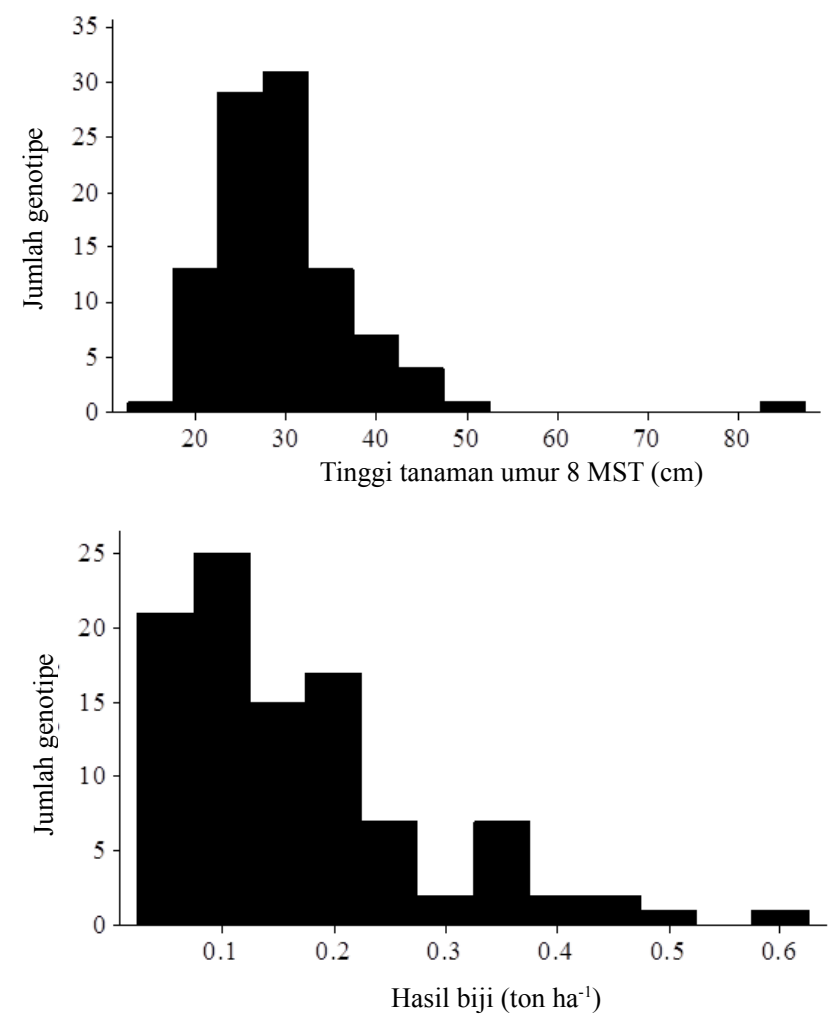

Gambar 2. Distribusi frekuensi skor pertumbuhan, tinggi tanaman, bobot brangkasan, dan hasil biji 100 genotipe kacang hijau di lahan salin Lamongan, Mei-Juli 2016 
Tabel 3. Skor pertumbuhan, bercak daun, tinggi tanaman, bobot brangkasan, bobot 100 biji, hasil biji, dan indeks panen genotipe kacang hijau pada tanah salin, Lamongan, Mei-Juli 2016

\begin{tabular}{|c|c|c|c|c|c|c|c|c|}
\hline \multirow{2}{*}{$\begin{array}{l}\text { No. } \\
\text { genotipe }\end{array}$} & \multirow{2}{*}{ Nama genotipe } & \multicolumn{2}{|c|}{$\begin{array}{c}\text { Skor } \\
\text { pertumbuhan }\end{array}$} & \multirow{2}{*}{$\begin{array}{l}\text { Skor } \\
\text { bercak } \\
\text { daun }\end{array}$} & \multirow{2}{*}{$\begin{array}{c}\text { Tinggi } \\
\text { tanaman } \\
8 \mathrm{MST} \\
(\mathrm{cm})\end{array}$} & \multirow{2}{*}{$\begin{array}{c}\text { Bobot } \\
\text { brangkasan } \\
5 \text { tanaman } \\
\text { (g) }\end{array}$} & \multirow{2}{*}{$\begin{array}{c}\text { Bobot } \\
100 \text { biji } \\
(\mathrm{g})\end{array}$} & \multirow{2}{*}{$\begin{array}{c}\text { Hasil } \\
\left(\text { ton ha }{ }^{-1}\right)\end{array}$} \\
\hline & & $4 \mathrm{MST}$ & $6 \mathrm{MST}$ & & & & & \\
\hline 81 & MMC 678-8c-gt-5 & 1 & 1 & 3 & 45.8 & 139.5 & 5.42 & 0.60 \\
\hline 73 & Vima1/MLG 1065-290 & 3 & 3 & 4 & 38 & 58.5 & 5.82 & 0.49 \\
\hline 63 & MLG 1065/Vima1-279 & 1 & 1 & 4 & 84.5 & 85.0 & 4.69 & 0.45 \\
\hline 58 & MLG 1065/Vima1-272 & 1 & 3 & 4 & 38.5 & 61.5 & 5.03 & 0.43 \\
\hline 69 & Vima1/MLG 1065-286 & 1 & 1 & 4 & 47.5 & 45.5 & 4.86 & 0.41 \\
\hline 62 & MLG 1065/Vima1-276 & 1 & 1 & 5 & 35.9 & 63.0 & 4.33 & 0.38 \\
\hline 76 & MMC 464c-gt-4-0-3 & 1 & 1 & 3 & 38.7 & 71.5 & 5.33 & 0.37 \\
\hline 94 & Vima2 & 3 & 3 & 5 & 31.9 & 61.0 & 4.8 & 0.35 \\
\hline 70 & Vima1/MLG 1065-287 & 1 & 3 & 5 & 32.1 & 45.5 & 4.88 & 0.35 \\
\hline 84 & MMC 267c-mn-1-1 & 3 & 3 & 3 & 46.2 & 101.5 & 5.29 & 0.33 \\
\hline 90 & MMC 641d-gt-4 & 3 & 3 & 5 & 36.1 & 55.0 & 4.47 & 0.33 \\
\hline 44 & Vima1/Sampeong// Vima1 & 1 & 1 & 4 & 36.2 & 48.0 & 4.59 & 0.33 \\
\hline 60 & MLG 1065/Vima1-274 & 1 & 3 & 5 & 35.7 & 46.0 & 5.57 & 0.33 \\
\hline 4 & MMC 679 - 3C - GT - 1/Vima 1 & 2 & 5 & 3 & 25.5 & 38.0 & 4.34 & 0.30 \\
\hline 71 & VIMA 1/MLG 1065-288 & 2 & 5 & 3 & 28.5 & 70.5 & 5.27 & 0.28 \\
\hline 96 & Murai & 3 & 1 & 4 & 39.4 & 82.0 & 5.31 & 0.27 \\
\hline 98 & Sriti & 3 & 3 & 4 & 32.6 & 76.0 & 5.39 & 0.22 \\
\hline 95 & Vima3 & 3 & 3 & 5 & 30.4 & 43.0 & 4.45 & 0.22 \\
\hline 99 & Walet & 1 & 3 & 4 & 46.0 & 105.5 & 4.59 & 0.21 \\
\hline 100 & Kenari & 1 & 3 & 5 & 42.2 & 48.0 & 5.34 & 0.20 \\
\hline 86 & Kutilang & 3 & 5 & 5 & 32.3 & 66.0 & 5.89 & 0.17 \\
\hline 97 & Perkutut & 5 & 7 & 5 & 28.0 & 38.0 & 4.61 & 0.15 \\
\hline \multirow[t]{3}{*}{87} & Vima1 & 3 & 7 & 5 & 29.1 & 33.5 & 4.04 & 0.11 \\
\hline & Rata-rata 100 genotipe & & & & & & & 0.17 \\
\hline & Batas seleksi $(\mathrm{X}+\mathrm{Sd})$ & & & & & & & 0.28 \\
\hline
\end{tabular}

Keterangan: MST= minggu setelah tanam

terdapat serangan bercak daun. Tanaman yang sangat peka mempunyai skor pertumbuhan 5-7, tinggi tanaman $20 \mathrm{~cm}$, panjang dan lebar daun $8 \mathrm{~cm}$ dan $6 \mathrm{~cm}$, intensitas serangan bercak daun yang parah pada permukaan daun.

Nilai koefisien keragaman genetik (KKG) tergolong rendah hingga tinggi antara 3.04-58.5\%. Tinggi tanaman, bobot brangkasan, umur berbunga, bobot 100 biji, serta bobot polong dan biji memiliki nilai KKG antara 14.0$58.5 \%$. Nilai KKG terendah ditunjukkan oleh umur berbunga dan tertinggi pada hasil biji diikuti bobot polong dan bobot brangkasan. Heritabilitas (arti luas) merupakan nisbah antara besaran ragam genotipik terhadap ragam fenotipik. Nilai heritabilitas (arti luas) untuk hasil, bobot polong, dan bobot brangkasan cukup tinggi antara 0.57-0.64 (Tabel 1). Dengan demikian faktor genetik memiliki peran cukup besar dalam menentukan toleransi terhadap salinitas.
Korelasi genetik $\left(r_{G}\right)$ dan fenotipik $\left(r_{p}\right)$ yang searah, erat dan positif ditunjukkan antara hasil dengan tinggi tanaman saat panen $\left(r_{G}=0.89^{* *}\right.$ dan $\left.r_{P}=0.71^{* *}\right)$, hasil dengan bobot brangkasan saat panen $\left(\mathrm{r}_{\mathrm{G}}=0.97^{* *}\right.$ dan $\left.\mathrm{r}_{\mathrm{P}}=0.89^{* *}\right)$, tinggi tanaman saat panen dengan bobot brangkasan saat panen $\left(\mathrm{r}_{\mathrm{G}}\right.$ $=0.97^{* *}$ dan $\left.r_{\mathrm{p}}=0.69^{* *}\right)$. Hal tersebut menunjukkan genotipe yang toleran salin akan memiliki postur tanaman tinggi, bobot brangkasan dan hasil yang tinggi pula. Sebaliknya genotipe peka salin akan diikuti dengan postur tanaman pendek, serta bobot brangkasan dan hasil biji rendah.

Diantara 100 genotipe yang diuji, 37 genotipe mempunyai hasil lebih dari rata-rata $\left(0.17\right.$ ton $\left.\mathrm{ha}^{-1}\right)$, dan termasuk dalam kelompok ini adalah varietas Vima 2, Murai, Vima 3, Sriti, Walet, Kenari, dan Kutilang dengan kisaran hasil $0.17-0.60$ ton $\mathrm{ha}^{-1}$, dan skor pertumbuhan 1 sampai 3 (toleran) (Tabel 3). Rendahnya hasil, selain disebabkan 
oleh cekaman salinitas yang tinggi, juga karena intensitas serangan penyakit bercak daun yang tinggi (skor 4-5). Skor serangan mengacu pada (Wongpiyasatid et al., 1999). Pada pengujian di rumah kaca, varietas Vima 1 toleran hingga DHL 6.40-12.49 dS m ${ }^{-1}$, varietas Murai, Kenari, Sriti, Betet toleran hingga DHL 2.87-5.68 dS m ${ }^{-1}$, varietas Kutilang, Sampeong, Perkutut, Merpati, dan Walet toleran hingga DHL 1.79-2.65 dS m ${ }^{-1}$ (Taufiq dan Purwaningrahayu, 2013).

Berdasarkan hasil, terpilih 15 genotipe yang tergolong toleran dengan tingkat hasil antara $0.28-0.60$ ton $\mathrm{ha}^{-1}$ atau lebih dari rata-rata ditambah simpangan baku ( 0.28 ton $\left.\mathrm{ha}^{-1}\right)$. Dari 15 genotipe tersebut, satu diantaranya adalah varietas Vima $2\left(0.35\right.$ ton $\left.\mathrm{ha}^{-1}\right)$, sedangkan 14 genotipe lainnya adalah galur generasi lanjut. Enam genotipe yang sangat toleran salin adalah MLG 1065/Vima1-279, MMC 464c-gt-4-0-3, MMC 678-8c-gt-5, Vima 1/MLG 1065-286, MLG 1065/Vima1-276 dan Vima1/Sampeong//Vima1-249, serta 7 genotipe yang tergolong toleran salin adalah Vima1/ MLG1065-290, MLG1065/Vima1-272, MLG1065/Vima1274, Vima1/MLG 1065-287, Vima1/MLG 1065-276, MMC 267c-mn-1-1-11, dan VIMA 1/MLG 1065-288 (Tabel 3). Genotipe tersebut memiliki skor pertumbuhan 1-5 (sangat toleran hingga agak toleran), agak tahan penyakit bercak daun (skor 3), tinggi tanaman 31.9-84.5 cm, dan bobot 100 biji 4.33-5.57 g (ukuran sedang). DHL tanah lingkungan

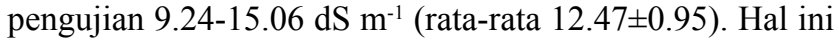
menunjukkan bahwa varietas Vima2 dan 14 galur tersebut toleran salin hingga DHL 9.24-15.06 dS m². Dari 100 genotipe yang diuji pada lahan salin, varietas Kutilang mempunyai bobot 100 biji tertinggi yakni 5.89 g. Pada kondisi normal, bobot 100 biji varietas Kutilang lebih dari 7 g, dengan demikian cekaman salin juga sangat berpengaruh terhadap ukuran biji.

Pada tanaman kacang hijau salinitas menyebabkan penurunan tinggi tanaman, jumlah polong, bobot 1,000 biji, menghambat pemasakan polong, dan biji keriput (Hossain et al., 2008; Ahmed 2009, Sehrawat et al., 2014). Pada padi, tanaman toleran cekaman salin memperlihatkan pertumbuhan karakter agronomi yang lebih baik (Utama et al., 2009), dan perbedaan diantara genotipe adalah terjadinya penurunan tinggi tanaman, bobot tajuk dan akar, dan luas daun serta degradasi klorofil a, total klorofil, dan total karetinoid (Situmorang et al., 2010).

\section{KESIMPULAN}

Sebagian besar genotipe (81\%) yang diuji tergolong peka hingga sangat peka pada cekaman salinitas berat (DHL tanah 9.24-15.06 $\mathrm{dS} \mathrm{m}^{-1}$ ). Semua genotipe dapat melewati fase generatif dan menghasilkan 2-9 polong per tanaman, dan hasil biji berkisar antara 0.04-0.60 ton ha ${ }^{-1}$. Genotipe yang toleran pertumbuhannya normal, dan memiliki tinggi tanaman, bobot brangkasan, serta hasil lebih tinggi dibandingkan genotipe yang peka. Enam genotipe terindikasi sangat toleran, yaitu MLG 1065/Vima1-279, MMC 464cgt-4-0-3, MMC 678-8c-gt-5, Vima 1/MLG 1065-286, MLG 1065/Vima1-276 dan Vima1/Sampeong//Vima1-249, dan tujuh genotipe terindikasi toleran, yaitu Vima1/MLG1065290, MLG1065/Vima1-272, MLG1065/Vima1-274, Vima1/
MLG 1065-287, Vima1/MLG 1065-276, MMC 267c-mn1-1-11, dan VIMA 1/MLG 1065-288.

\section{DAFTAR PUSTAKA}

Abou-Baker, N.H., M. Abd-Eladl, M.A. Mohsen. 2011. Use of silicate and different cultivation practices in alleviating salt stress effect on bean plants. Australian J. Basic Applied Sci. 5:769-781.

Ahmed, S. 2009. Effect of salinity on the yield and yield component of mungbean. Pakistan J. Bot. 41:263268.

Alharbi, A. 2015. Effect of mulch on soil properties under organic farming conditions in center of Saudi Arabia. J. American Sci. 11:108-115.

Cardon, G.E., J.G. Davis, T.A. Bauder, R.M. Waskom. 2007. Managing Saline Soils. Colorado State University. US.

Dutta, P., A.K. Bera. 2014. Effect of salinity on seed germination and seedling growth on mungbean cultivars. Legume Res. 37:161-164.

Gregorio, G.B., D. Senadhira, R.D. Mendoza. 1997. Screening rice for salinity tolerance. IRRI Discussion Paper Series.

Hossain, M.M., M.N.A. Miah, M.A. Rahman, M.A. Islam, M.T. Islam. 2008. Effect of salt stress on growth and yield attributes of mungbean. Bangladesh Res. Pub. J. 1:324-336.

Jones, J.B. 2002. Agronomic Handbook: Management of crops, soil, and their fertility. CRC Press, New York.

Kandil, A.A., A.A. Arafa, A.E. Sharief, A.N. Ramadan. 2012. Genotypic different between two mungbean varieties in response to salt stress at seedling stage. Int. J. Agric. Sci. 4:278-283.

Kumar, S.B., M. Prakash, S. Narayanan, J. Gokulakrishnan. 2012. Breeding for salinity tolerance in mungbean. APCBEE Procedia 4:30-35.

Mensah, J.K., J. Ihenyen. 2009. Effects of salinity on germination, seedling establishment and yield of three genotypes of mungbean (Vigna mungo L. Hepper) in Edo State, Nigeria. Nigerian Ann. Nat. Sci. 8:17- 24.

Murillo-Amador, B., E. Troyo-Dieguez, J.L. GarciaHernandez, R. Lopez-Aquilar, N.Y. Avila-Serrano, S. Zamora-Salgado, E.O. Rueda-Puente, C. Kaya. 2006. Effect of $\mathrm{NaCl}$ salinity in the genotypic variation of cowpea (Vigna uguiculata) during early vegetative growth. Sci. Hort. 108:423-431. 
Naher, N., A.K.M.M. Alam. 2010. Germination, growth and nodulation of mungbean (Vigna radiata L.) as affected by sodium chloride. Int. J. Sustain. Crop Prod. 5:8-11.

Saha P., P. Chatterjee, A.K. Biswas. 2010. NaCl pretreatment alleviates salt stress by enhancement of antioxidant defense and osmolyte accumulation in mungbean (Vigna radiata L. Wilczek). Indian J. Exp. Biol. 48593-600.

Sehrawat N., K.V. Bhat, R.K. Sairam, P.K. Jaiwal. 2014. Screening of mungbean [Vigna radiata (L.) Wilczek] genotypes for salt tolerance. Int. J. Plant Animal Environ. Sci. 4:36-43.

Sehrawat, N., M. Yadav, K.V. Bhat, R.K. Sairam, P.K. Jaiwal. 2015. Effect of salinity stress on mungbean [Vigna radiata (L.) Wilczek] during consecutive summer and spring seasons. J. Agric. Sci. 60:23-32.

Singh, D.P., B.B. Singh. 2011. Breeding for tolerance to abiotic stresses in mungbean. J. Food Legumes 24:83-90.

Situmorang, A., A. Zannati, D. Widyajayantie, S. Nugroho. 2010. Seleksi genotipe padi mutan insersi toleran cekaman salinitas berdasarkan karakter pertumbuhan dan biokimia. J. Agron. Indonesia 38:8-14.

Swarup, A. 2013. Sustainable management of salt-affected soils and poor-quality of ground waters for enhanching crop production. p. 327-334. In S.A. Shahid, M.A. Abdelfattah, F.K. Taha (Eds.). Development in Soil Salinity Assesment and Reclamation: Innovative Thinking and Use of Marginal Soil and Water Resources in Irrigated Agriculture. Springer Sci. and Busines, Dordrecht. 801 pages. DOI 10.1007/97894-007-5684-7.
Taufiq, A., R.D Purwaningrahayu. 2013. Tanggap varietas kacang hijau terhadap cekaman salinitas. J. Pen. Pert. Tan. Pangan 32:161-172.

Trustinah, R.Iswanto, R.T. Hapsari. 2016. Toleransi galur F3 kacang hijau terhadap cekaman salinitas. hal. 489-497. Dalam A.A. Rahmianna, Sholihin, A. Taufiq, Suharsono, N. Saleh, E. Ginting, F. Rozi, I.K. Tastra, Hermanto, E. Yusnawan, D. Harnowo (Eds.). Prosiding Seminar Nasional Hasil Penelitian Tanaman Aneka Kacang dan Umbi 2015. Puslitbangtan.

Utama, M.Z., W. Haryoko, R. Munir, Sunadi. 2009. Penapisan varietas padi toleran salinitas pada lahan rawa di Kabupaten Pesisir Selatan. J. Agron. Indonesia 37:101-106.

Vekariya, H.B., H.J. Revar. 2010. Groundnut Breeding. Genetic variability, diversity, correlation, and path coefficient analysis in bunch groundnut (Arachis hypogaea L.). Lap Lambert Academic Publishing, Germany.

Wongpiyasatid, A., S. Chotechuen, P. Hormchan, M. Srihuttagum. 1999. Evaluation of yield and resistance to powdery mildew, Cercospora leaf spot and cowpea weevil in mungbean mutant lines. Kasetsart J. (Nat. Sci.) 33:204-215.

Yadav, S., I. Mohammad, A. Aqil, H. Shamsul. 2011. Causes of Salinity and Plant Manifestations to Salt Stress: A review. J. Environ. Biol. 32:667-685.

Zhang, Q.T., M. Inoue, K. Inosako, M. Irshad, K. Kondo, Guo Yu Qiu, Shi Ping Wang. 2008. Ameliorative effect of mulching on water use efficiency of Swiss chard and salt accumulation under saline irrigation. J. Food Agric. Environ. 6:480-485. 